\title{
PECULARITIES OF ELECTRON BEAM WELDING OF HOT-ROLLED ALUMINUM-LITHIUM ALLOYS*
}

\begin{abstract}
D. Drimal, M. Kasencak, F. Kolenic, A. Kramarcik, L. Kovac
PRVA ZVARACSKA a. s. Kopcianska 14, 85101, Bratislava, Slovak Republic. E-mail: drimal.daniel@pzvar.sk

This paper presents results of experiments on electron beam welding of Al-Li alloys. The wrought AW 2099 alloy was used as experimental material. AW 2099 alloy in T83 condition of thickness $25 \mathrm{~mm}$ was used. The microstructure of experimental alloy was degraded by annealing and deformation before welding. The original thickness $25 \mathrm{~mm}$ was reduced to $3 \mathrm{~mm}$ by hot rolling without any subsequent additional heat treatment. The full penetration butt-welds and T-joint configurations were made by electron beam. These welded joints underwent investigation of basic mechanical testing (tensile strength, bending, hardness) and metallographic inspection for internal defects and microstructure identification. Welded joints didn't have significant internal defects, but tensile strength and plastic properties were deteriorated significantly by welding process and previous deformation. The heat treatment was performed for improvement of mechanical and plastic properties. The heat treatment mode consists of solution treatment (annealing) followed by quenching and subsequent aging cycles. 5 Ref., 5 Tabl., 8 Fig.
\end{abstract}

Keywords: aluminum-lithium alloys, electron beam welding, macrostructure of weld, tensile strength test

Aluminium alloys alloyed by lithium can be included in the category of high strength light alloys. These alloys are mostly used in aviation and space industry. Lithium as alloying element results into reduction of specific weight and increase of modulus of elasticity, while lithium effect is much stronger compared to others alloying elements. Addition of Li promotes formation of strong strengthening phases and increase of fatigue crack resistance. Recent investigations of Al-Li alloys resulted in formation of new generation of alloys. These alloys are characterized by not only weight reduction, but also improvement of properties such as corrosion resistance, good strength and ductility, and workability such as machining, forging, bending, and welding [1-4].

To get best results of Al-Li alloys in terms of mechanical properties it is necessary to perform $\mathrm{T} 8$ treatment. The treatment consists of solution treatment, quenching, cold deformation and artificial treatment, which is a key factor to achieve desired structure and uniform precipitation. Cold deformation is necessary for generation of dislocation network that works as nuclei for strengthening phases formation with finer microstructure and development of conditions for precipitation in grain boundary regions. Phases on grain boundaries are unfavourable in terms of material toughness.

The Al-Li alloys are grouped by weldability [5]. Degradation of structural and mechanical properties of weld metal and HAZ should be taken into account due to welding heat cycle. The welding methods with limited heat input are favourable for joining $\mathrm{Al}-\mathrm{Li}$ alloys. The most common defects in fusion welds and HAZ are porosity, hot cracks and microstructure degradation. Porosity is caused mainly by lithium reactivity. Lithium is present in structure not only in form of phases, but also in form of different compounds (such as carbonate, hydroxide or hydride). These compounds decay due to effect of heat and form various gases that can be entrapped in the weld metal mostly in the weld root area. Porosity can be reduced by mechanical or chemical treatment of surface or weld metal stirring. Hot cracking susceptibility is caused by formation of low melting eutectics. Formation of hot cracks can be suppressed by using pulse current, reduction of heat input, reduction of stresses in welded joint area or by combination of these methods. Mechanical properties of Al-Li alloys welded joints can be reduced to $50 \%$ of mechanical properties of base metal. Mechanical properties degradation in weld metal and HAZ is caused by increase of phases that cannot used for strengthening. Using welding methods allowing limitation of heat input is preferable for Al-Li alloy joining. The compressor impellers working in less aggressive environments can be the next application field of Al-Li alloys. Low specific weight and favourable mechanical properties allow reducing moment of inertia and therefore energy consumption of these machines. Impeller wheels of compressors are parts with complex shape and their production without joining technologies is in some cases extremely expensive and sometimes impossible. The

\footnotetext{
*Based on materials presented at IX International Conference «Beam Technologies in Welding and Materials Processing», September 9-13, 2019, Odessa, Ukraine.
} 


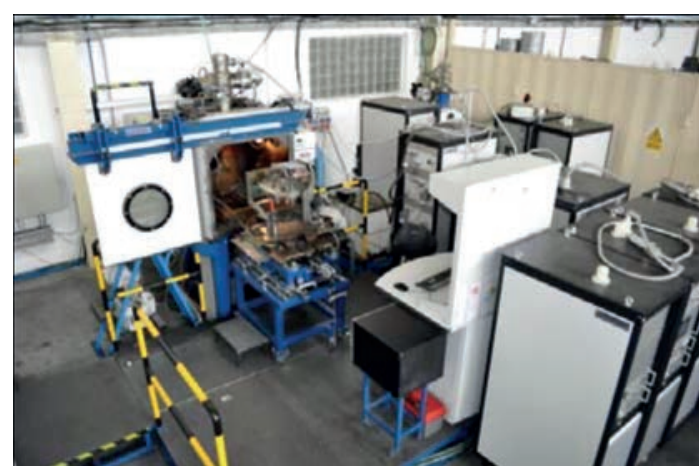

Fig. 1. Workplace of electron-beam complex PZ EZ 4

impeller consists of two hub discs among which are slots. There are number of different designs and manufacturing approaches with some advantages and disadvantages. And the production issues are caused primary by difficult-to-reach welded joint. Two basic types of impeller design are welded by electron beam in PRVÁ ZVÁRAČSKÁ a. s. Company. The first design is based on two hub discs fabricated by milling and each disc includes half of the blade. Discs are joined by butt weld in the middle of the blade. Another design is chosen for impellers with narrow channel (less than $4 \mathrm{~mm}$ ). In the case of narrow channel impeller, one hub disc is milled with full blade and impeller is covered by second disc. The second hub disc is joined to the blades by T-weld.

Methods and materials. The aim of the work was to investigate possibilities of production of propeller wheels made of Al-Li alloys by electron beam welding and evaluate the achieved results of mechanical properties.

The technology development and experiments were carried out on an experimental classification PZ EZ 4 (Fig. 1). The universal electron beam complex for welding and surface treatment of materials is equipped with 3 -axis positioning system continuously controlled and synchronized with technology. For powering the electron gun, the PZ EB $2.5-15$ is used to generate an electron beam with accelerating voltage up to $60 \mathrm{kV}$ and output up to $15 \mathrm{~kW}$. The arbitrary waveform generator ETC M631 is integrated

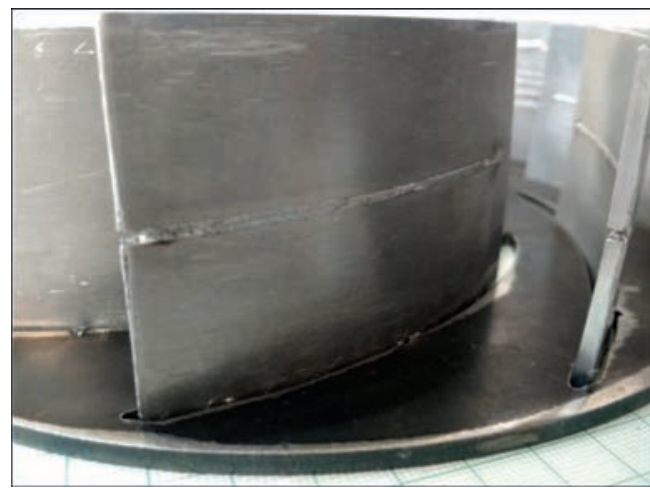

Fig. 2. Model impeller with test blade
Table 1. Nominal chemical composition of AW 2099 alloy

\begin{tabular}{|c|c|c|c|}
\hline Element & Content, wt.\% & Element & Content, wt.\% \\
\hline $\mathrm{Cu}$ & $2.4-3.0$ & $\mathrm{Ti}$ & $0.10 \max$ \\
\hline $\mathrm{Li}$ & $1.6-2.0$ & $\mathrm{Fe}$ & $0.07 \max$ \\
\hline $\mathrm{Zn}$ & $0.4-1.0$ & $\mathrm{Si}$ & $0.05 \max$ \\
\hline $\mathrm{Mg}$ & $0.10-0.50$ & $\mathrm{Be}$ & $0.0001 \mathrm{max}$ \\
\hline $\mathrm{Mn}$ & $0.10-0.50$ & Others, Each & $0.05 \max$ \\
\hline $\mathrm{Zr}$ & $0.05-0.12$ & Others, Total & $0.15 \max$ \\
\hline
\end{tabular}

into the control system, which is used to control the electron beam deflection system.

AW 2099 alloy. Wrought AW 2099 alloy was used as experimental material (Tabl. 1). AW2099 alloy was used in T83 condition with thickness $25 \mathrm{~mm}$. The microstructure of experimental alloy was degraded by annealing and deformation before welding. The original thickness $25 \mathrm{~mm}$ was reduced to $3 \mathrm{~mm}$ by hot rolling without any subsequent additional heat treatment. The full penetration butt-welds and T-joint configurations were made by electron beam.

These welded joints underwent visual inspection, basic mechanical tests (tensile strength, bending, hardness) and metallographic examination for internal defects and microstructure identification.

Heat treatment. The part of welded samples was subjected to heat treatment. Heat treatment consists of solution treatment at $T=540{ }^{\circ} \mathrm{C}$ for 90 minutes followed by quenching into water. Next step was artificial ageing at temperature $T=160{ }^{\circ} \mathrm{C}$ for 18 hours. The temperatures and times for heat treatment have been chosen on the basis of available information from literature.

The research of joining technology was carried for both previously mentioned designs (butt weld BW - blade joining and T-weld disc and blade joining. The welding procedures were proposed based on experiences with welding of titanium and steel impellers for both approaches. Because of preliminary tests and cost reduction the welding experiments were performed only with model impellers. Only blades were fabricated from AW 2099 alloy. The model discs were fabricated from mild steel and contained the slot in which the blades were inserted. The straight blades'

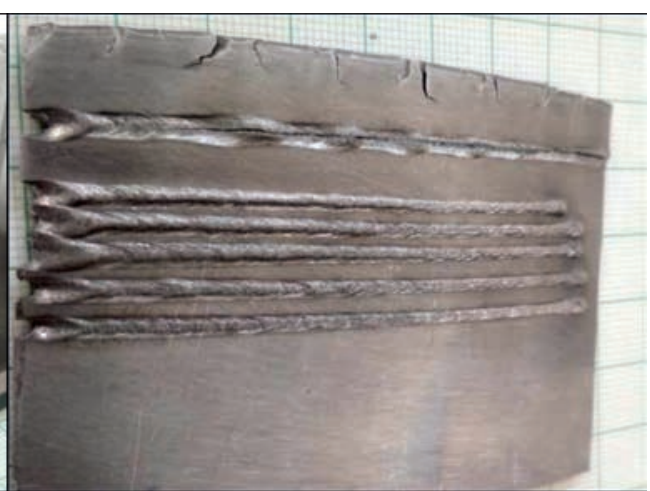


Table 2. Final welding parameters for joining impeller by EBW through blade

\begin{tabular}{|c|c|}
\hline Accelerating voltage $U, \mathrm{kV}$ & 55 \\
\hline Initial welding current $I_{\mathrm{w}}, \mathrm{mA}$ & 40 \\
\hline Welding speed $v_{\mathrm{w}}, \mathrm{mm} \cdot \mathrm{s}^{-1}$ & 25 \\
\hline Initial focal current $I_{\mathrm{f}}, \mathrm{mA}$ & 800 \\
\hline Final defocus $I_{\mathrm{f}}, \mathrm{mA}$ & +10 \\
\hline Dynamic deflection & $\begin{array}{c}\sin 1500 \mathrm{~V} / \cos 1500 \mathrm{~V} ; \\
(0.5 \mathrm{~mm}) f=1000 \mathrm{~Hz}\end{array}$ \\
\hline
\end{tabular}

design was used for samples with regard to further investigation of mechanical properties.

Butt weld - blade welding. Welding process parameters were adjusted based on trials with model impellers (Fig. 2). The welding process was developed for constant accelerating voltage $U=55 \mathrm{kV}$. The welding current speed and focal position were set to achieve full penetration of the blade. Final parameters are listed in Tabl. 2.

Production of T-weld to the blades through hub disc. Joining by T-weld through hub disc is used in case of narrow channel where BW - blade joining cannot be used because of electron beam dimensions. In this case the blade is part of hub disc and joint is formed by melting of blade disc interface. The welding process and test samples were made using simple T-joint configuration from AW 2099 sheets of $3.0 \mathrm{~mm}$ for simplification. The weld penetration is not the main factor of weld strength in the case of T-weld. The weld strength is determined by weld width in the disc-blade interface. However, this weld width is limited by blade thickness and its thermal capacity. This unwelded area not only reduces effective weld width, but also acts as notch in the weld. The notch effect can
Table 3. Final welding parameters for joining impeller by T-weld through disc

\begin{tabular}{|c|c|}
\hline Accelerating voltage $U, \mathrm{kV}$ & 55 \\
\hline Initial welding current $I_{\mathrm{w}}, \mathrm{mA}$ & 45 \\
\hline Focal current $I_{\mathrm{w}}, \mathrm{mA}$ & 807 \\
\hline Welding speed $v_{\mathrm{w}}, \mathrm{mm} \cdot \mathrm{s}^{-1}$ & 30 \\
\hline
\end{tabular}

be reduced by inserting brazing filler material to the joint and by application of hybrid welding process to some extent.

Advantage of this method is constant welding process over the entire length of the blade without necessity of change of welding current or focal position. Another benefit is absence of spatter in the impeller channel, in case of proper process setup.

At the same time the determination of actual weld penetration, as well as nonwelded area dimensions are complicated when ultrasonic testing method is applied.

Welding parameters were set by trials based on full penetration welding of sheet of $3.0 \mathrm{~mm}$ thickness. The set welding current was increased by $5 \mathrm{~mA}$ to secure sufficient penetration to the blade. The circular patter dynamic deflection of electron beam was used to increase weld width in the disc-blade interface. Used welding parameters are listed in Tabl. 3.

Results. Surface of samples of butt weld was uniform without significant imperfections such as undercut, excessive weld metal, surface porosity, cracks or spatters. Visual inspection of BW indicated excessive penetration. The root height was less than $0.5 \mathrm{~mm}$ over the whole weld length (Fig. 3). Penetration inspection does not reveal any indications.

The surface of T-weld was uniform over the entire weld length without presence of spatters, porosity or

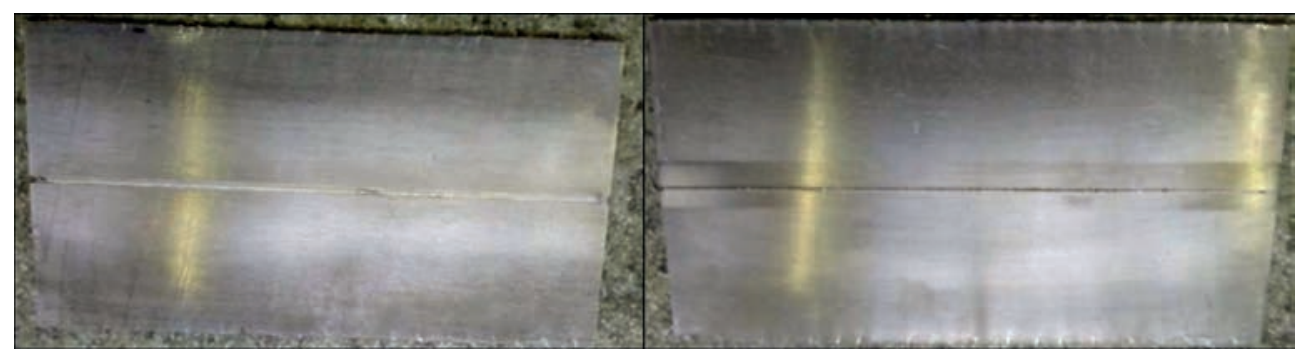

Fig. 3. Surface and root of butt weld sample
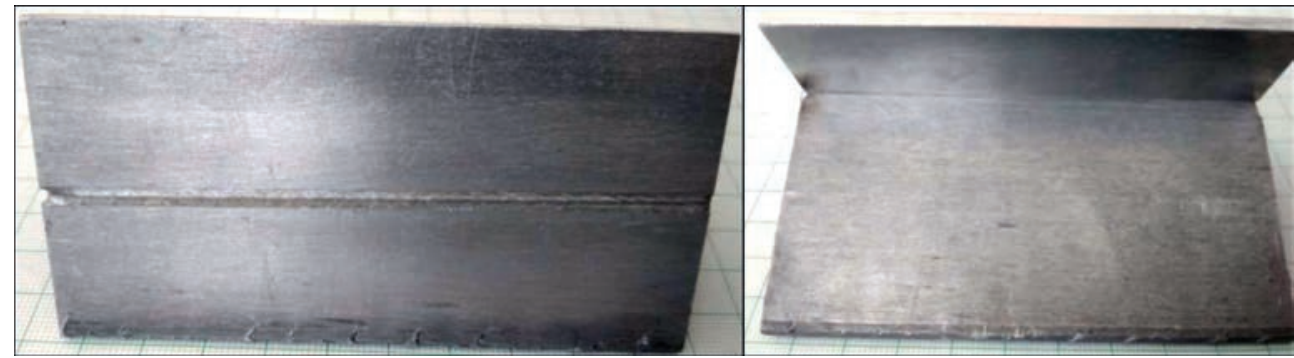

Fig. 4. Surface of T-weld 


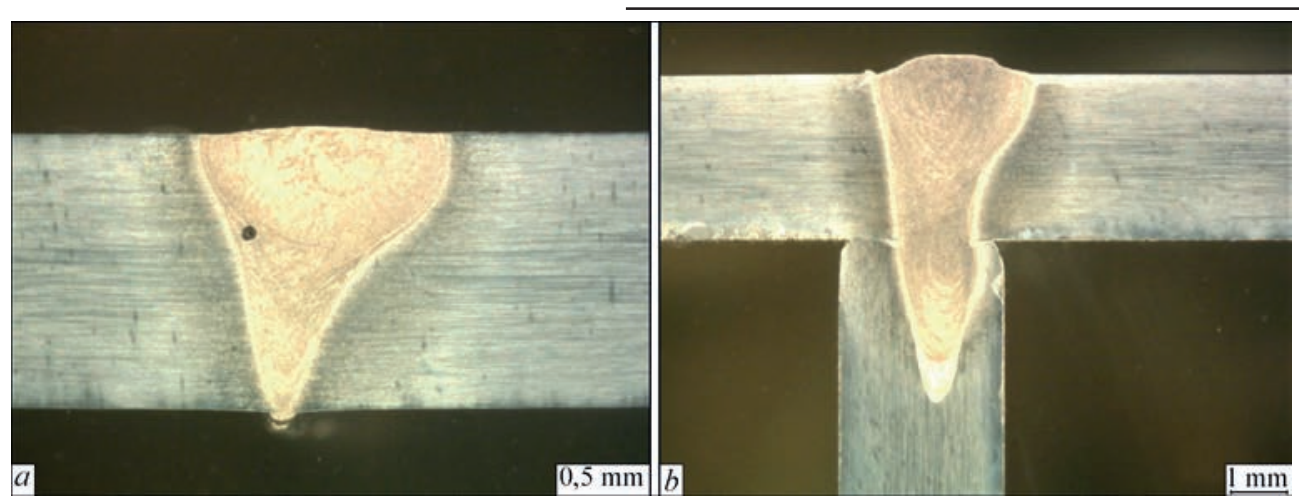

Fig. 5. Macrostructure of weld without heat treatment: $a-\mathrm{BW} ; b-\mathrm{T}$-weld

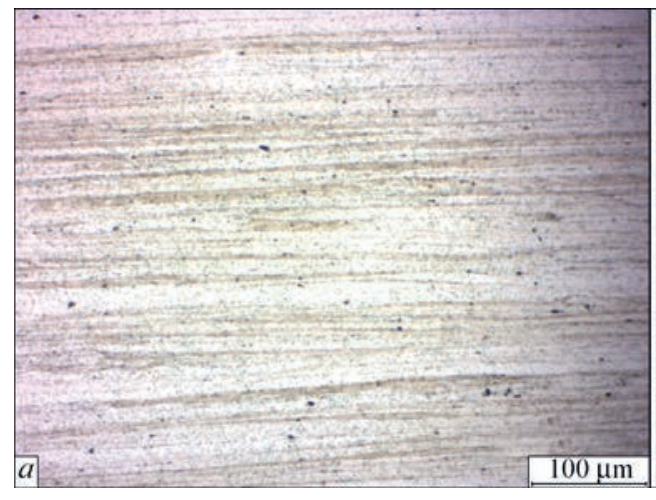

Fig. 6. Microstructure of base metal: $a-$ without heat treatment; $b$ cracks. No root penetration was observed out of blade material (Fig. 4).

Macrostructure. Macrostructure of butt (Fig. 5,a) weld reveals weld with full penetration without presence of any cracks. The weld metal includes one pore with diameter approx. $0.1 \mathrm{~mm}$. HAZ is not significant and its width is up to $1.5 \mathrm{~mm}$. Width of weld metal reaches $2.7 \mathrm{~mm}$ on the surface. Measured root width is $0.5 \mathrm{~mm}$. The shape of weld shows some asymmetry probably because of fixture residual magnetisms.

T-weld (Fig. 5, $b$ ) is not placed perfectly in the axis of blade and weld axis is shifted by $0.3 \mathrm{~mm}$. Weld is $1.4 \mathrm{~mm}$ wide on the disc-blade interface and this width is proportional to T-weld strength. HAZ is not very significant similarly to $\mathrm{BW}$.

Microstructure. Microstructure of base metal consists of grains elongated in the rolling direction

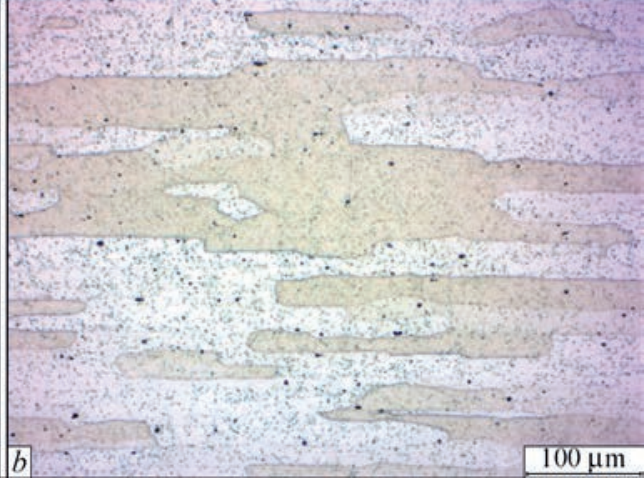

- with heat treatment

with precipitated strengthening particles (Fig. 6, a). The nature of microstructure does not change noticeably after heat treatment (solution annealing with water, quenching and artificial ageing) only grain growth can be observed and phases are finer (Fig. 6, b).

We can observe surface appearance changes in the HAZ because of recrystallization during welding cycle (Fig. 7, $a$ ). The fusion zone is formed by fine globular grains. The structure shows some grain growth after heat treatment cycle.

Weld metal has columnar shaped grains near the fusion zone. The axis of the grains is oriented in the steepest heat gradient. The columnar grains are transformed into polyedric grains. The phases are mainly in the grain boundary region in case of samples without heat treatment cycle (Fig. 8, a). The grain growth also takes place in weld metal during heat treatment

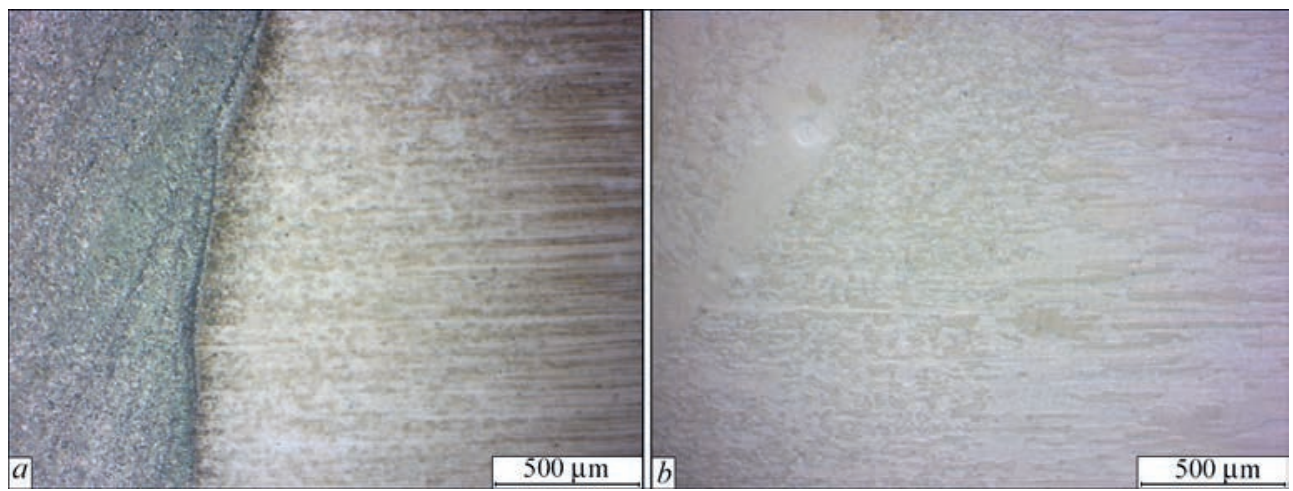

Fig. 7. Microstructure of HAZ: $a$ - without heat treatment; $b$ - with heat treatment 


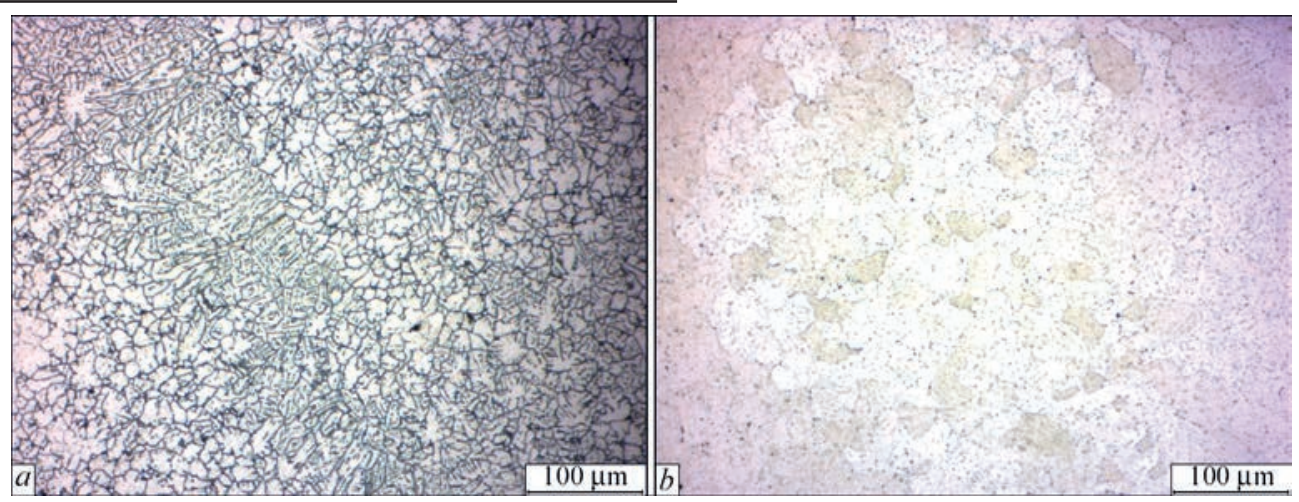

Fig. 8. Microstructure of weld metal: $a$ - without heat treatment; $b$ - with heat treatment

Table 4. Result of tensile strength test of weld joints with and without heat treatment cycle

\begin{tabular}{|c|c|c|c|c|c|c|c|}
\hline Sample & \multicolumn{2}{|c|}{ Yield strength, $R_{\mathrm{p} 0.2}, \mathrm{MPa}$} & \multicolumn{2}{c|}{ Tensile strength, $R_{\mathrm{m}}, \mathrm{MPa}$} & Note \\
\hline Base metal without heat treatment & 410.5 & 405.2 & 407.4 & 434.3 & 428.3 & 428.0 & $A=2 \%$ \\
\hline BW without heat treatment & - & - & - & 281.1 & 284.0 & 282.8 & Failure in fusion zone \\
\hline BW with heat treatment & 283.7 & 284.5 & 278.3 & 409.0 & 405.7 & 407.0 & Failure in base metal \\
\hline T-weld without heat treatment & - & - & - & 58.5 & 58.6 & 58.2 & Failure in weld metal \\
\hline T-weld with heat treatment & 109.3 & 114.0 & 114.9 & 128.0 & 133.3 & 132.5 & Failure in weld metal \\
\hline
\end{tabular}

Table 5. Results of bend test of butt welded joints with and without heat treatment cycle

\begin{tabular}{|c|c|c|c|c|}
\hline Sample & \multicolumn{3}{|c|}{ Bend angle, $^{\circ}$} & Failure localization $^{\circ}$ \\
\hline BW without heat treatment & 16 & 11 & 9 & Failure in weld metal \\
\hline BW with heat treatment & 180 & 180 & 180 & No failure \\
\hline
\end{tabular}

cycle (Fig. 8, $b$ ). And the phases distribution is more uniform and phases are fine after heat treatment cycle (Fig. 8, b).

The static tensile strength (Tabl. 4) and bend test (Tabl. 5) were performed so far. The base metal after solution treatment and thickness reduction from $25.0 \mathrm{~mm}$ to $3.0 \mathrm{~mm}$ reaches tensile strength over $R_{\mathrm{m}}=428 \mathrm{MPa}$ and yield strength $R_{\mathrm{p} 0.2}=405 \mathrm{MPa}$, but elongation was only $A=2 \%$. The degradation of mechanical properties due to heat cycle takes place as expected. The tensile strength decreased by a third to over $281 \mathrm{MPa}$ for the butt weld. Measured tensile strength was only $58 \mathrm{MPa}$ in case of T-weld. This significant drop is also verified by calculation. The width of the blade was taken for calculation, not only weld width. The heat treatment cycle allows restoring to $94 \%$ (over $405 \mathrm{MPa}$ ) of the original tensile strength in case of butt weld. Tensile strength was doubled by heat treatment to the value of over $128 \mathrm{MPa}$ for T-weld. The failure of the samples without heat treatment occurs in fusion zone during tensile tests. The strength of weld metal was higher in comparison with base metal after heat treatment and therefore the failure takes place in base metal.

The bend test was performed with mandrel of $D=35 \mathrm{~mm}$ diameter with regard to the low plastic properties of original base metal $(A=2 \%)$. This size of mandrel was used also for bend test of welded joints after heat treatment for better comparison. Samples of butt weld without heat treatment cycles rupture at bend angle from $9^{\circ}$ to $16^{\circ}$. The failure was located in weld metal in all cases. No failure was observed after bend test of samples with heat treatment at bend angle of $180^{\circ} \mathrm{C}$ (Tabl. 5).

\section{Conclusions}

The achieved result showed suitability of chosen approach for application of Al-Li alloys in production of low stressed impeller with reduced power consumption. Proper setup of electron beam process results in production of sound welds with high quality. Over $94 \%$ of original value of tensile strength was reached for butt weld using heat treatment cycle for improvement of the plastic properties. Bend angle of $180^{\circ}$ was achieved for these samples.

The negative effect of welding heat impact on mechanical properties was identified as expected. This negative impact can be effectively suppressed by heat treatment cycle after welding. Optimum combination of solution treatment temperature and time together with artificial ageing can restore the properties almost to the original values.

It is necessary to focus on the way how to increase the width of T-weld to the maximum achievable size to secure the highest strength of the welded joint.

Further work has to be done in the field investigation of dynamical properties and parameters for optimization of heat treatment cycle in or- 
der to increase mechanical and plastic properties.

Acknowledgments. This work was supported by the Slovak Research and Development Agency under the contract No. APVV-15-0337, APVV-16-0300, APVV17-0432 and by Ministry of Education, Science, Research and Sport of the Slovak Republic within the project Req-00048-0005.

\section{References}

1. Hrivňák, I. Zváranie a zvaritel'nost' materiálov. (2009) $V$ Bratislave: Slovenská technická univerzita. Edícia vysokoškolských učebníc. ISBN 978-80-227-3167-6.
2. Metalwebnews: Lithium aluminium alloys - the new generation aerospace alloys. Metal Web News, (C2007 https://web. archive.org/web/20070928094349/http:/www.metalwebnews.com/howto/alloys/alloys.pdf

3. Lin Y., Zheng Z.Q., Li S.C. (2013) Effect of solution treatment on microstructures and mechanical properties of 2099 Al-Li alloy. [cit. 2019-01-24]. DOI: https://doi.org/10.1016/j. acme.2013.07.005

4. Rioja, Roberto J., Liu John. (2012) The evolution of Al-Li base products for aerospace and space applications. Metallurgical and Materials Transact. A. Springer, US, 43(9), 33253337. DOI: https://doi.org/10.1007/s11661-012-1155-Z

5. Wang, S., HuangY., Zhao L. (2017) Effects of different aging treatments on microstructures and mechanical properties of $\mathrm{Al}-\mathrm{Cu}-\mathrm{Li}$ alloy joints welded by electron beam welding. [cit. 2019-01-24]. DOI: https://doi.org/10.1016/j.cja.2017.07.002

\section{ОСОБЛИВОСТІ ЕЛЕКТРОННО-ПРОМЕНЕВОГО ЗВАРЮВАННЯ ГАРЯЧЕКАТАНИХ АЛЮМІНІЕВО-ЛІТІЕВИХ СПЛАВІВ}

D. Drimal, M. Kasencak, F. Kolenic, A. Kramarcik, L. Kovac

PRVA ZVARACSKA a. s. Копчанська 14, 85101, Братислава, Словацька Республіка. E-mail: drimal.daniel@pzvar.sk

У даній роботі представлені результати експериментів з електронно-променевого зварювання сплавів Al-Li. Прокат зі сплава AW 2099 в поставці Т83 товщиною 25 мм був використаний в якості експериментального матеріалу. Мікроструктура експериментального сплаву була деградована після відпалу та деформації перед зварюванням. Початкова товщина 25 мм була зменшена до 3 мм гарячим прокатом без подальшої додаткової термічної обробки. Прорізні зварні шви та шви Т-з'єднання виконані електронним променем. Ці зварні з'єднання пройшли основні механічні випробування (міцність на розрив, вигин, твердість) та металографічний огляд на предмет виявлення внутрішніх дефектів та мікроструктури. Зварені з'єднання не мали значних внутрішніх дефектів, але міцність на розрив та пластичні властивості значно погіршилися внаслідок зварювального процесу та попередньої деформації. Термічну обробку проводили для поліпшення механічних та пластичних властивостей. Режим термічної обробки складається з обробки на твердий розчин (відпал) з подальшими циклами загартування та старіння. 5 Бібліогр., 5 табл., 8 рис.

Ключові слова: алюмінієво-літієві сплави, електронно-променеве зварювання, макроструктура зварного шва, випробування на міцність, на розрив

Received 18.10.2019

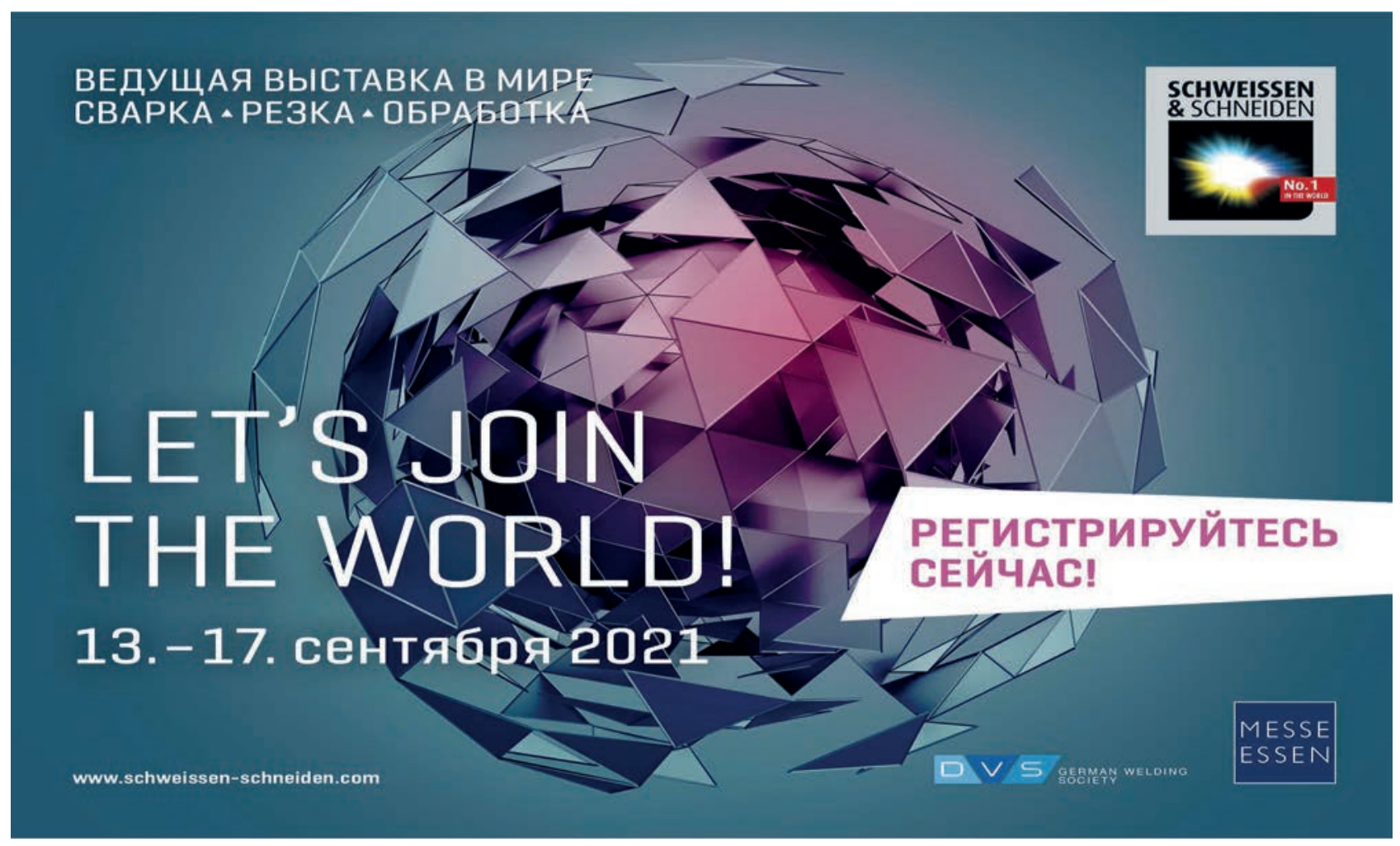

